\title{
Catalytic properties of binary and ternary alloys based on silver
}

\author{
M.Ved, M.Glushkova, N.Sakhnenko \\ National Technical University "Kharkiv Polytechnical Institute", \\ 21 Frunze St., 61002 Kharkiv, Ukraine
}

Received August 1, 2012

\begin{abstract}
The correlation between the morphology, composition and catalytic properties of silvercobalt alloys has been shown. The galvanic Ag-Co alloy is established as synergetic ones, and the values obtained for the exchange current density of the model hydrogen evolution reaction are similar to platinum. The catalytic activity testing results of binary (Ag-Co) and ternary (Ag-Co-Zr, Ag-Co-Bi) alloys in the carbon monoxide oxidation to carbon dioxide were analyzed.
\end{abstract}

\begin{abstract}
Показана взаимосвязь между каталитическими свойствами, морфологией и составом сплава серебро-кобальт. Установлено, что гальванический сплав Ag-Со является синергетическим, а полученные значения плотности тока обмена модельной реакции выделения водорода близки к платине. Проанализированы результаты тестирования каталитической активности бинарных $(\mathrm{Ag}-\mathrm{Co})$ и тройных $(\mathrm{Ag}-\mathrm{Co}-\mathrm{Zr}, \mathrm{Ag}-\mathrm{Co}-\mathrm{Bi})$ сплавов в реакциях окисления монооксида углерода до углекислого газа.
\end{abstract}

\section{Introduction}

The modern technologies development in the electronic devices production, power and mechanical engineering is impossible without the miniaturization and high purity operations, which, in turn, requires the use of materials with a wide range of functional properties. One of their creation ways is to build thin functional coatings on the surface of traditional industrial materials. Such coatings must have a corrosion resistance, magnetic properties, catalytic activity, for example - silver alloys with ignoble (silver - cobalt, silver - bismuth) metals [1].

The noble metals are essential, and in some cases the singular catalysts for major industrial processes including the production of high-octane gasoline, etc. Platinum and palladium are the main components of catalysts for exhaust gases neutralization of internal combustion engines, flue gases of oil refining and petrochemical industries, several chemical plants [2].
Nowadays, multi-component catalysts based on transition metals and their oxides are the most widely used in different media due to the high cost of noble metals [3-5]. They represent a significant interest as inexpensive catalytically active materials for electrochemical and heterogeneous redox reactions [6].

Electrochemical methods of the coatings synthesis based on transition metals [7, 8] provide a flexible control of the composition, surface morphology and, consequently, the functional property (catalytic activity) of the materials, by the varying the electrolyte composition and electrolysis modes. The purpose of this work is to establish the relationship between the surface coating morphology, composition and catalytic properties of binary and ternary alloys in CO oxidation reaction.

\section{Experimental}

Electrochemical experiments in the work were performed in a three-electrode glass cell at room temperature without electrolyte 


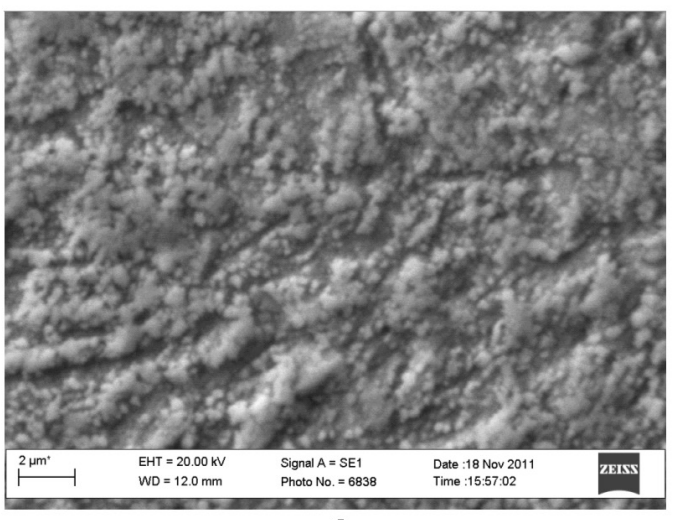

a

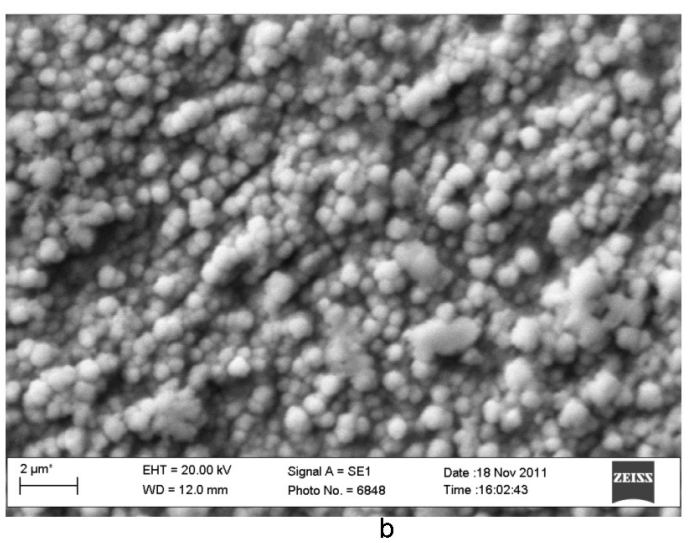

Fig. 1. Current density effect on the surface morphology $(\times 5000)$ of silver-cobalt alloy deposited under pulse mode at $t_{i} / t_{p}=5 / 50 \mathrm{~ms}$ and $j, \mathrm{~A} / \mathrm{dm}^{2}: 0.5$ (a), 5 (b).

stirring. The binary (Ag-Co) and ternary ( $\mathrm{Ag}-\mathrm{Co}-\mathrm{Zr}$ ) and $\mathrm{Ag}-\mathrm{Co}-\mathrm{Bi}$ ) coatings were deposited from citrate-pyrophosphate electrolyte (sodium citrate $0.5 \mathrm{M}$; potassium pyrophosphate $0.5 \mathrm{M})$ onto substrates of copper at pH 9-10 [9]. The necessary $\mathrm{pH}$ value was set by sodium hydroxide addition. The coatings of $1.5 \mu \mathrm{m}$ thickness were deposited using pulse mode: unipolar current of $j=0.5 \ldots 5 \mathrm{~A} / \mathrm{dm}^{2}$ (Ag-Co), $j=0.5 \ldots 1 \mathrm{~A} / \mathrm{dm}^{2}$ (Ag-Co-Zr), $j=$ $8 . . .12 \mathrm{~A} / \mathrm{dm}^{2}$ (Ag-Co-Bi) densities. The pulse and pause duration was $t_{i}=2 . .5 \mathrm{~ms}$ and $t_{p}=20 . . .50 \mathrm{~ms}$, frequency $(f)-19 \ldots 45.5 \mathrm{~Hz}$ [10]. The alloys chemical composition was determined by X-ray fluorescence method using a portable spectrometer "SPRUT", and the coatings surface morphology was examined using a scanning electron microscope ZEISS EVO 40XVP. The catalytic properties of electrodeposited alloys coatings with different compositions were preliminary estimated using the exchange current value $j^{0}{ }_{\mathrm{H} 2}$ of the model hydrogen evolution reaction from sodium hydroxide solution. The cell was deoxygenated by purging with high purity argon for $15 \mathrm{~min}$. Then, the polarization was realized using a PI-50-1.1 potentiostat and PR-8 programmer. The potential was measured by silver chloride reference electrode and recalculated to the hydrogen scale. Catalytic properties testing in carbon monoxide oxidation reaction was carried out in a tubular flow reactor from quartz glass with coaxially wound heating coil. Initial mixture of $\mathrm{CO}$ and air was supply to the reactorinlet at a rate of $0.025 \mathrm{l} / \mathrm{min}$ and at a concentration of $1 \%$ vol. Reactor temperature was increased from 20 to $420^{\circ} \mathrm{C}$. CO content in the final mixture was analyzed using an indicatoranalyzer "Dozor".

\section{Results and discussion}

Taking into account the previously established mechanism and kinetics regularities of silver - iron group metal co-deposition into alloy [11, 12], we focused our attention on the effect of electrolysis modes on the composition, morphology and functional properties. The metals codeposition occurs at the potentials of $-2.4 \ldots-2.8 \mathrm{~V}$, so completely logical that silver content in Ag-Co alloy decreases from 20 to 8 wt. \% with increasing amplitude of the pulse current in the range of $0.5 \ldots 5 \mathrm{~A} / \mathrm{dm}^{2}$. At the same time, the current efficiency declines to $70 \%$ due to the intensification of hydrogen evolution reaction. The change of the on/off time ratio, pulse frequency and pulse/pause duration allowed to vary the noble component content in $\mathrm{Ag}-\mathrm{Co}$ alloy in the range of \pm 10 wt. \%. Variation of components ratio in the solution leads to the change in composition of the electrolytic alloy. So, silver content in the alloy is up to $38 \mathrm{wt} . \%$ at $c\left(\mathrm{Co}^{2+}\right) / c\left(\mathrm{Ag}^{+}\right)=1: 1$ and at current density $2 \mathrm{~A} / \mathrm{dm}^{2} \quad\left(t_{i} / t_{p}=2 / 20 \mathrm{~ms}\right)$, and at the $c\left(\mathrm{Co}^{2+}\right) / c\left(\mathrm{Ag}^{+}\right) \stackrel{p}{=} 10: 1-7$ wt. \% with current efficiency $99 \%$. Thus, it is possible to synthesize $\mathrm{Ag}-\mathrm{Co}$ alloys with silver content of 7 to 38 wt. \%, varying the parameters of the electrolysis pulsed mode (current density, frequency and on/off time ratio, pulse/pause duration) and composition of citrate-pyrophosphate electrolyte.

Fine-grained, bright, uniform in thickness and homogeneous surface coatings with $\omega(\mathrm{Ag})=21 \mathrm{wt} . \%$ are formed at the low current densities in the pulse mode (Fig. 1a). Growth $\omega$ (Co) to 93 wt. \% (Fig. 1b) is achieved by increasing the current density and effect on the deposits surface structure: dark and mat coating with devel- 


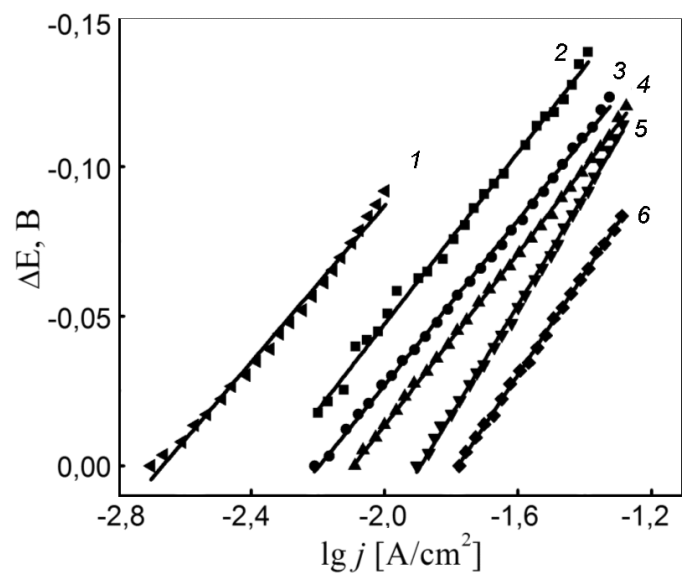

Fig. 2. Overpotential of hydrogen evolution on the Ag-Co alloy compared to Pt (1) with $\omega(\mathrm{Ag})$ in the coatings, wt. $\%: 2-38 ; 3-$ $23 ; 4-12 ; 5-9 ; 6-7$.

oped surface is deposited. In addition to the alloys element, carbon and oxygen incorporate into the coating, content of which depends on the current density. So, carbon content was $11 \mathrm{wt} \%$, and oxygen $-7 \mathrm{wt}$. $\%$ at the current density $j=0.5 \mathrm{~A} / \mathrm{dm}^{2}$ and decreased to 5.5 wt. $\%$ and 4 wt. $\%$ at the $j=5 \mathrm{~A} / \mathrm{dm}^{2}$, respectively.

Electrocatalytic properties of the $\mathrm{Ag}-\mathrm{Co}$ alloys coating with different contents of the noble metal were assessed based on results of the polarization dependences, constructed in the Tafel coordinates (Fig. 2).

The tilt angle of the linear plots varied depending on the platinum and Ag-Co alloy coatings polarization, which indicated a change of the hydrogen evolution mechanism. The values of the universal kinetic characteristic of the process - the ex-

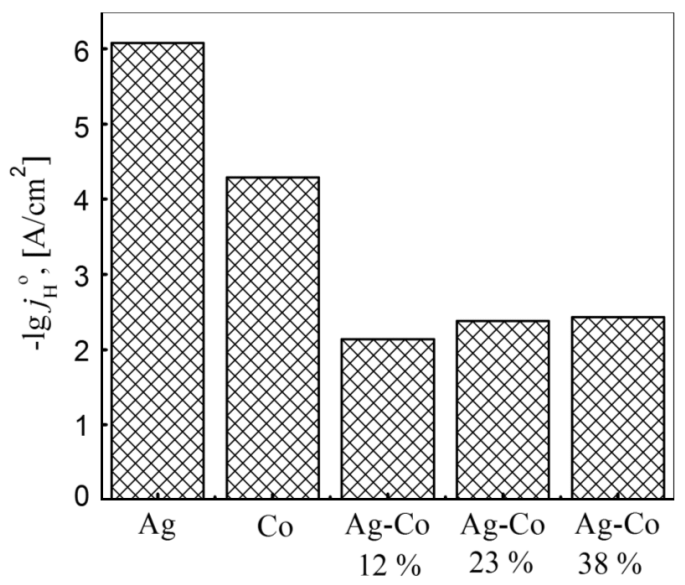

Fig. 3. Exchange current density in the model hydrogen evolution reaction on the metals $\mathrm{Ag}$, Co and Ag-Co alloys of different composition.

change current density $j_{\mathrm{H}}^{0}$ (Fig. 3), and Tafel coefficients (a, b) (Table), reflect the influence of electrode nature on the reactions kinetics, but also allow to compare the catalytic properties of the electrodes, even in quasi-equilibrium conditions.

The obtained data allow to suggest that the galvanic $\mathrm{Ag}-\mathrm{Co}$ alloy has a synergistic effect on the catalytic properties. The results showed that the optimum, from the standpoint of electrocatalytic activity, compared to platinum is Ag-Co alloy with silver content of 12 wt. \%, as it has an extensive and uniform across the surface structure, which may exceed the geometric dimensions to ten times.

Catalytic activity of the electrolytic binary and ternary alloys coatings in the oxidation reaction of carbon monoxide were as-

Table. Dependence of Ag-Co alloy coatings electrocatalyst characteristics on its composition

\begin{tabular}{|c|c|c|c|}
\hline \multirow{2}{*}{$\begin{array}{l}\text { Electrode material, } \\
\text { metal content } \omega, \\
\text { wt. } \%\end{array}$} & \multicolumn{2}{|c|}{ Tafel constant } & \multirow{2}{*}{$\begin{array}{l}\text { Hydrogen exchange } \\
\text { current density }-\lg j_{\mathrm{H}}^{0}, \\
{\left[\mathrm{~A} / \mathrm{cm}^{2}\right]}\end{array}$} \\
\hline & $-a, \mathrm{~V}$ & $-b, \mathrm{~V}$ & \\
\hline Pt [13] & 0.31 & 0.10 & 3.1 \\
\hline $\mathrm{Pt}_{\text {exp. }}$ & 0.30 & 0.10 & 3.0 \\
\hline $\mathrm{Ag}[13]$ & 0.73 & 0.12 & 6.1 \\
\hline Co $[13]$ & 0.60 & 0.14 & 4.3 \\
\hline $\mathrm{Ag}-\mathrm{Co} ; \omega(\mathrm{Ag})=38$ & 0.34 & 0.14 & 2.43 \\
\hline $\mathrm{Ag}-\mathrm{Co} ; \omega(\mathrm{Ag})=23$ & 0.31 & 0.13 & 2.38 \\
\hline $\mathrm{Ag}-\mathrm{Co} ; \omega(\mathrm{Ag})=12$ & 0.30 & 0.14 & 2.14 \\
\hline $\mathrm{Ag}-\mathrm{Co} ; \omega(\mathrm{Ag})=9$ & 0.35 & 0.17 & 2.06 \\
\hline $\mathrm{Ag}-\mathrm{Co} ; \omega(\mathrm{Ag})=7$ & 0.30 & 0.16 & 1.87 \\
\hline
\end{tabular}


sessed by the ignition temperature $T_{i}$ and the conversion degree of carbon monoxide to the dioxide [14]:

$$
X=\frac{c(\mathrm{CO})_{i}-c(\mathrm{CO})_{f}}{c(\mathrm{CO})_{i}} \cdot 100 \%,
$$

where, $c(\mathrm{CO})_{i}$ and $c(\mathrm{CO})_{f}$ the initial and final $\mathrm{CO}$ concentrations at the reactor outlet, $\%$.

As can be seen from the temperature dependence (Fig. 4) the reaction of $\mathrm{CO}$ oxidation starts at the temperature of $200^{\circ} \mathrm{C}$ on platinum catalyst $(\omega(\mathrm{Pt})=100$ wt. $\%)$. For the binary silver-cobalt alloy with $\omega(\mathrm{Ag})=$ $7 \mathrm{wt} . \%$. the ignition temperature is $250^{\circ} \mathrm{C}$.

The increase of the noble component to 21 wt. \% in the alloy allows reducing the start work of the catalyst at $10^{\circ} \mathrm{C}$. So, the highest values of catalytic activity in a model oxidation reaction of $\mathrm{CO}$ to $\mathrm{CO}_{2}$ characteristic for the alloy, which has a more homogeneous structure and developed surface.

In addition to the binary silver-cobalt alloy, catalyst activity of ternary alloys was investigated (Fig. 4). Thus, the ignition temperature for Ag-Co-Bi alloy coating was $220^{\circ} \mathrm{C}$ at $\omega(\mathrm{Bi})=12$ wt. $\%$ and $\omega(\mathrm{Ag})=21$ wt. \% .

For the first time, it was investigated ternary Ag-Co-Zr alloy, in which a codeposition of rare-earth element made possible due the use of the electrolysis pulsed mode. $\mathrm{Ag}-\mathrm{Co}-\mathrm{Zr}$ alloy with the content of zirconium to 1 wt. \%. showed a high catalytic activity in comparison with platinum. The rare earth metal incorporation to 1 wt. \%. in silver-cobalt-zirconium alloy showed high values on the catalytic activity, which were comparable with platinum (Fig. 4). It should be noted that the conversion degree for the ternary Ag-Co-Zr alloy and Pt was $100 \%$ at the temperature of $250^{\circ} \mathrm{C}$. Note that the conversion degree of carbon monoxide to carbon dioxide for a ternary $\mathrm{Ag}-\mathrm{Co}-\mathrm{Zr}$ alloy and $\mathrm{Pt}$ is $100 \%$ at $250^{\circ} \mathrm{C}$.

Thus, the properties of the binary and ternary alloys coatings based on silver are in full accordance to earlier assumptions about the synergistic character of alloys and about the correlation composition - properties [1] for the indicated elements and confirm the perspective of using materials as catalysts for neutralization of carbon monoxide.

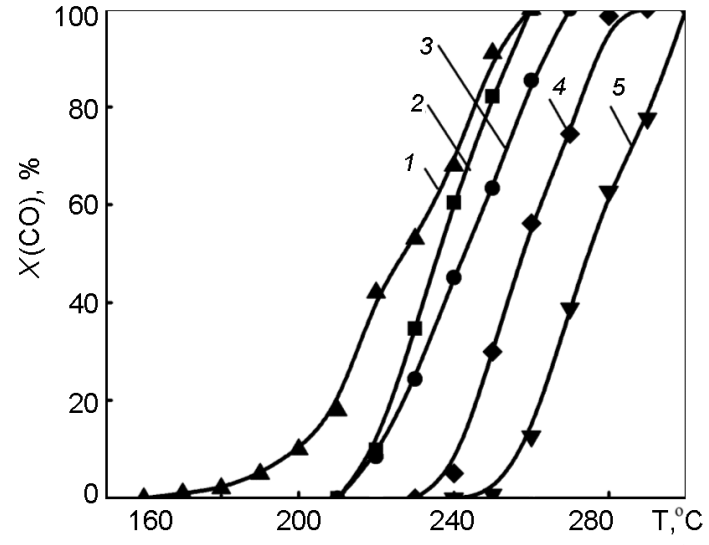

Fig. 4. Thermogram of the carbon monoxide conversion degree for Pt (1), ternary: Ag-Co$\mathrm{Zr}$ (2), Ag-Co-Bi (3) and binary Ag-Co alloys with a silver content, wt. \%: 21 (4), 7 (5).

\section{Conclusions}

Our studies have established the correlation between silver-cobalt alloy composition, catalytic properties and surface coatings morphology. Thus, the highest catalytic activity had Ag-Co alloy with a fine-grained structure and content of the noble component of 12 wt. \%. It was established that the high catalytic properties are possessed ternary alloys; in particular, $\mathrm{Ag}-\mathrm{Co}-\mathrm{Bi}$ alloy with the content of bismuth to 12 wt. \%. and $\mathrm{Ag}-\mathrm{Co}-\mathrm{Zr}$ alloy with the content of zirconium to $1 \mathrm{wt}$. $\%$. reduce the ignition temperature on $20^{\circ} \mathrm{C}$ to the values comparable with platinum. The conversion degree of such coatings is $100 \%$.

Thus, the ternary and binary synergistic alloys based on silver can be substitute for platinum catalysts, and used as an alternative catalytically-active material in gas emissions converter of automobile transport and industrial plants.

\section{References}

1. M.D.Sakhnenko, M.V.Ved, The Catalytic and Protective Coating Alloys and Complex Oxides: Electrochemical Synthesis, Properties Prediction, NTU "KhPI", Kharkov (2010) [in Russian].

2. N.M.Popova, The Catalysts for Exhaust Gas Purification from Industrial Plants, Chemistry, Moscow (1991) [in Russian].

3. C.Guldur, F.Balikci, Chem. Engin. Commun., 5, 190 (2010).

4. E.Gulari, S.Srivannavit et al., Appl. Catalyst, 182, 147 (1999).

5. H.Ichitsubo, Y.Horiuchi et al., Appl. Catalyst, 173, 37 (1998). 
6. M.Luo, X.Yaun et al., Appl. Catalyst, 175, 121 (1998).

7. S.Valizadeh, G.Holmbom et al., Surf. and Coat. Techn., 105, 213 (1998).

8. S.Nineva, I.Krastev et al., Bulgarian Chem. Commun., 43, 88 (2011).

9. Ukr. Patent 68386 (2012).

10. Ukr. Patent 68415 (2012).
11. M.Glushkova, L.Savchenko et al., Questions of Chem. and Chem. Techn., 4, 132 (2011).

12. M.Ved, M.Glushkova, Vesnik NTU "KhPI", 30, 97 (2010).

13. A.N.Frumkin, The Electrode Processes, Science, Moscow (1987) [in Russian].

14. P.V.Snytnikov, V.D.Belyaev et al., Kinetics and Catalysis, 1, 100 (2007)

\title{
Каталітичні властивості бінарних та потрійних сплавів на основі срібла
}

\author{
М.В.Ведь, М.О.Глушкова, М.Д.Сахненко
}

\begin{abstract}
Показано взаємозв'язок між каталітичними властивостями, морфологією і складом сплаву срібло-кобальт. Встановлено, що гальванічний сплав $\mathrm{Ag}-\mathrm{Co}$ є сінергетичним, a отримані значення густини струму обміну модельної реакції виділення водню близькі до платини. Проаналізовано результати тестування каталітичної активності бінарних (Ag-Co) та потрійних (Ag-Co- $\mathrm{Zr}, \mathrm{Ag}-\mathrm{Co}-\mathrm{Bi})$ сплавів в реакціях окислення монооксиду вуглецю до вуглекислого газу.
\end{abstract}

